\title{
Pengaruh Integrasi Media Komunikasi terhadap Pengetahuan Pengunjung Wisata Edukasi Pertanian Desa Bono, Kecamatan Boyolangu, Kabupaten Tulungagung
}

\section{The Influence of Communication Media Integration on The Knowledge of Agricultural Education Tourism in Bono Village, Boyolangu District, Tulungagung Regency}

\author{
Mochlisin Fatkur Rohman*), Gunawan, Ugik Romadi
}

Politeknik Pembangunan Pertanian Malang 65200, Indonesia

${ }^{*}$ E-mail korespondensi: mochlisfatkur123@gmail.com

Diterima: 7 Juni 2021 | Disetujui: 15 Desember 2021 | Publikasi Online: 22 Desember 2021

\begin{abstract}
Indonesia has a lot of natural wealth that can be used as a ecotourism or tourism village. One of the tourism village developments is in Bono Village, Boyolangu Sub district, Tulungagung Regency. The tourism is Agricultural Education Tourism Belimbing Artha Mandiri Farmer Group. Agricultural education tourism is very potentially visited by tourists because of the quality of products and knowledge given to visitors. Agricultural education tourism managers must raise agricultural education in their tourism, because educational tourism aims to educate visitors about agricultural sciences, so the renewal communication media is necessary to support the achievement of these goals. The purpose this study is to describe the characteristics visitors and analyze the influence of visitor characteristics and the integration of communication media on the knowledge of visitors. The research method used is Descriptive Quantitative. Determination respondents' samples using proportionate stratified random sampling techniques, as well as data analysis used is multiple linear regression. The results of this study showed the level knowledge of visitors is at the stage of understanding and the presence a significant influence between the variable characteristics of visitors and the integration of communication media to the level knowledge of visitors.
\end{abstract}

Keywords: Agrotourism, agricultural education tourism, communication media integration, visitor characteristics, visitor knowledge level

\section{ABSTRAK}

Indonesia memiliki banyak kekayaan alam yang dapat dimanfaatkan sebagai wisata alam atau desa wisata. Salah satu pengembangan desa wisata ada di Desa Bono, Kecamatan Boyolangu, Kabupaten Tulungagung. Wisata tersebut bernama Wisata Edukasi Pertanian Kelompok Tani Belimbing Artha Mandiri. Wisata edukasi pertanian sangat berpotensi dikunjungi oleh wisatawan karena kualitas produk dan ilmu yang diberikan kepada pengunjung. Pengelola wisata edukasi pertanian harus mengunggulkan edukasi pertanian dalam wisatanya, karena wisata edukasi bertujuan untuk mengedukasi pengunjung terkait ilmu pertanian, maka pembaharuan media komunikasi perlu dilakukan agar dapat menunjang tercapainya tujuan tersebut. Tujuan dari penelitian ini adalah untuk mendeskripsikan karakteristik pengunjung serta menganalisis pengaruh karakteristik pengunjung dan integrasi media komunikasi terhadap pengetahuan pengunjung. Metode penelitian yang digunakan adalah Kuantitatif Deskriptif. Penentuan sampel responden menggunakan teknik proportionate stratified random sampling, serta analisis data yang digunakan adalah regresi linear berganda. Hasil penelitian ini menunjukkan tingkat pengetahuan pengunjung berada pada tahap memahami dan adanya pengaruh yang signifikan antara variabel karakteristik pengunjung dan integrasi media komunikasi terhadap tingkat pengetahuan pengunjung.

Kata kunci: Agrowisata, wisata edukasi pertanian, integrasi media komunikasi, karakteristik pengunjung, tingkat pengetahuan pengunjung

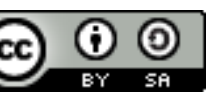




\section{PENDAHULUAN}

Indonesia memiliki banyak kekayaan alam yang dapat dimanfaatkan sebagai wisata alam yang berlokasi di pedesaan atau disebut dengan desa wisata. Salah satu pengembangan desa wisata ada di Desa Bono, Kecamatan Boyolangu, Kabupaten Tulungagung. Wisata tersebut bernama Wisata Edukasi Pertanian Kelompok Tani Belimbing Artha Mandiri. Wisata edukasi pertanian sangat berpotensi dikunjungi oleh wisatawan karena kualitas produk dan ilmu yang diberikan kepada pengunjung. Seiring dengan berkembangnya wisata lain berbasis alam yang berada di Kecamatan Boyolangu, membuat persaingan semakin ketat. Hal ini perlu diperhatikan oleh pengelola wisata edukasi pertanian agar wisata edukasi dapat bersaing dengan wisata yang lain. Selain itu organisasi pariwisata harus menjaga tingkat kualitas agar memungkinkan lebih banyak User Generated Content (UGC) sehingga akan meningkatkan kepercayaan dari pengunjung (Narangajavana et al., 2017).

Wisata edukasi harus mementingkan dari segi ilmu dan pengetahuan yang diberikan kepada pengunjung, sesuai dengan visi wisata edukasi yaitu mengedukasi dan memberi pemahaman mengenai bidang pertanian, khususnya budidaya belimbing organik. Selain itu, terdapat permodelan sistem pertanian secara keseluruhan perlu mengadopsi dan menyerap data mutakhir serta memanfaatkan teknologi informasi dan komunikasi dengan cepat dengan fokus pada kebutuhan sasaran dan manfaat yang dirasakan (Janssen et al., 2017 dan Farid, 2018).

Pada wisata edukasi pertanian media komunikasi yang digunakan belum optimal dan efektif sehingga berdampak pada kurangnya pengetahuan pengunjung mengenai materi yang telah diberikan. Hal itu juga disebabkan oleh kurangnya keterampilan pengelola dalam mengoperasikan media komunikasi yang lain, sehingga media komunikasi yang digunakan hanya sebatas personal serta hal itu sudah berjalan selama 2 tahun ini yaitu pada tahun 2018-2020. Selain itu pengelola wisata edukasi pertanian belimbing kelompok tani artha mandiri belum mengetahui sejauh mana media komunikasi mampu mempengaruhi tingkat pengetahuan pengunjung. Untuk mengatasi hal tersebut, maka perlu inisiasi mengoptimalkan media komunikasi sehingga dapat meningkatkan pengetahuan pengunjung.

Menurut Batubara (2011) dan Suri (2019), media komunikasi adalah suatu media atau alat bantu yang digunakan oleh suatu organisasi guna tercapainya efisiensi dan efektivitas kerja dengan hasil yang maksimal. Pemilihan media komunikasi dalam melaksanakan komunikasi yang efektif memegang peranan penting dalam menentukan keefektifan suatu interaksi komunikasi. Menurut Mittal \& Mehar (2016), berbagai sumber informasi yang mungkin saling melengkapi atau menggantikan satu sama lain dan juga mengimplikasikan bahwa sumber tunggal tidak memenuhi semua kebutuhan informasi pengunjung. Maka dari itu macam-macam media komunikasi dapat menunjang konten yang berhubungan subjektif untuk mendorong pengalaman pengunjung (Joo et al., 2020).

Untuk menunjang komunikasi yang lebih efektif, maka perlu adanya peningkatan media komunikasi yang digunakan. Dengan media pembelajaran yang beragam maka akan meningkatkan kualitas belajar sebagai upaya meningkatkan ilmu pengetahuan dan wawasan seseorang (Teni, 2018). Peningkatan tersebut dapat melalui integrasi media komunikasi seperti media personal, Instagram, Youtube, Facebook, Blogspot dan X-Banner sehingga diharapkan benar-benar mampu berdampak lebih baik terhadap pengetahuan pengunjung. Berdasarkan permasalahan yang ada, maka, penelitian ini bertujuan untuk mendeskripsikan karakteristik pengunjung serta menganalisis pengaruh karakteristik pengunjung dan integrasi media komunikasi (media personal, media sosial dan media cetak) terhadap pengetahuan pengunjung. Dengan tujuan tersebut, penelitian ini akan memberikan manfaat dan pengetahuan berupa perkembangan pemanfaatan media komunikasi untuk menunjang berjalannya komunikasi efektif di area wisata edukasi pertanian. Penggunaan media komunikasi yang beragam dan modern seperti media cetak berupa X-Banner, media instagram, facebook, blogspot dan youtube yang dihubungkan dengan pengetahuan atau intelektual pengunjung menjadikan penelitian ini berbeda dari penelitian-penelitian yang telah dilakukan sebelumnya.

\section{METODE}

Lokasi yang digunakan pada penelitian ini bertempat di Wisata Edukasi Pertanian Kelomok Tani Belimbing Artha Mandiri, Desa Bono, Kecamatan Boyolangu, Kabupaten Tulungagung. Penentuan lokasi penelitian dilakukan dengan purposive atau sengaja dipilih dengan pertimbangan sebagai berikut: 1) Termasuk Agrowisata atau wisata pertanian, 2) Salah satu tempat referensi wisata edukasi di Kabupaten Tulungagung, 3) Pengunjung yang datang cukup beragam dan ada setiap harinya, 4) 
Memiliki Media Komunikasi untuk menunjang penyampaian informasi, 5) Akses jalan menuju lokasi cukup mudah. Waktu yang digunakan untuk penelitian ini dari bulan Januari sampai dengan Maret 2021. Metode penelitian yang digunakan adalah Kuantitatif Deskriptif. Penelitian Kuantitatif Deskriptif merupakan jenis metode penelitian yang menggambarkan suatu objek dan subjek yang sedang diteliti tanpa adanya rekayasa. Termasuk mengenai hubungan tentang kegiatan, pandangan, sikap dan proses-proses yang berpengaruh dalam suatu fenomena yang terjadi.

Populasi dalam penelitian ini adalah pengunjung yang datang di Wisata Edukasi Pertanian Kelompok Tani Belimbing Artha Mandiri. Jumlah pengunjung di Wisata Edukasi Pertanian Kelompok Tani Belimbing Artha Mandiri diambil dari data time seires selama 1 bulan, yaitu sebanyak 129 pengunjung. Pada penelitian ini menggunakan teknik proportionate stratified random sampling. Teknik sampel proportionate stratified random sampling merupakan teknik penentuan sampel bila populasi mempunyai anggota/unsur yang tidak homogen dan berstrata secara proporsional (Sugiyono, 2018).

Dasar pengambilan sampel ini adalah disesuaikan dengan populasi selama 1 bulan yang ada di lapangan atau tempat wisata dan digunakan rumus proportionate stratified random sampling untuk mengetahui secara pasti sampel penelitian yang diperlukan. Kerangka sampel lebih jelasnya pada perhitungan dibawah ini:

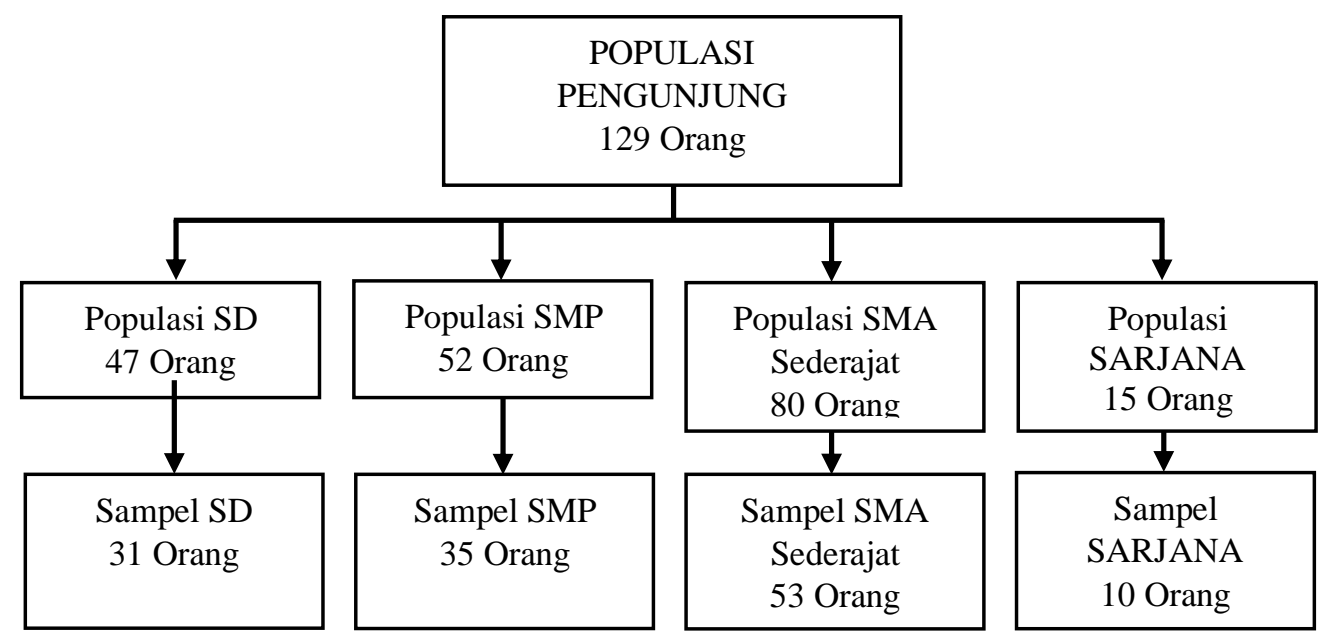

Berdasarkan data diatas maka dapat diperoleh sampel total berjumlah 129 orang. Terdiri dari sampel pendidikan SD 31 orang, pendidikan SMP 35 Orang, pendidikan SMA Se-derajat 53 orang dan pendidikan sarjana 10 orang. Teknik pengumpulan data yang dipakai pada kajian ini adalah teknik wawancara dan kuesioner. Dalam penelitian ini sasaran yang diwawancara adalah pengelola Wisata Edukasi Pertanian yang mengetahui informasi-informasi tentang media komunikasi dan juga pengunjung Wisata Edukasi. Kuesioner yang digunakan dalam penelitian ini berisikan tentang aspek pembentuk tingkat pengetahuan pengunjung terkait materi yang diberikan melalui media komunikasi yang digunakan. Untuk pembagian kuesioner secara online melalui google form yang dibagikan pada media sosial seperti Whatsapp, Instagram, Facebook dan Blogspot.

Variabel yang digunakan dalam penelitian ini adalah variabel karakteristik pengunjung (X1), meliputi sub variabel umur, tingkat pendidikan, pekerjaan dan tingkat pendapatan ; variabel integrasi media komunikasi (X2), meliputi media personal (langsung), media sosial (Instagram, Facebook, Youtube, Blogspot) dan media cetak ( X-Banner) ; Tingkat Pengetahuan Pengunjung (Y) (Tahu dan Memahami).

Analisis data yang digunakan dalam penelitian ini yaitu dengan menggunakan analisis regresi linier berganda melalui program SPSS (Statistical Product and servise Solution) 20. Analisis regresi linier berganda digunakan untuk mengetahui apakah ada pengaruh dari variabel $\mathrm{X}$ terhadap variabel $\mathrm{Y}$. Diduga variabel karakteristik pengunjung (umur, tingkat pendidikan, pekerjaan dan tingkat pendapatan) dan integrasi media komunikasi (media personal, media sosial dan media cetak) berpengaruh terhadap tingkat pengetahuan pengunjung). Tahapan yang dilakukan untuk menganalisa data yang telah diteliti adalah sebagai berikut : (1) Persiapan Data (Tabulasi Data), (2) Estimasi Model 
Regresi Linear (Berganda), (3) Pengujian Asumsi Klasik, (4) Uji Kelayakan Model (Goodness of Fit Model), (5) Interprestasi Model Regresi Linear (Berganda).

\section{HASIL DAN PEMBAHASAN}

\section{Umur Pengunjung}

Tabel 1. Distribusi Pengunjung Berdasarkan Umur

\begin{tabular}{clcc}
\hline No. & Umur & Jumlah (Orang) & Persentase (\%) \\
\hline 1. & Kanak-kanak (5-11) & 2 & 2 \\
2. & Remaja (12-25) & 67 & 51 \\
3. & Dewasa (26-45) & 49 & 38 \\
4. & Lansia (46-65) & 11 & 9 \\
\hline Jumlah & 129 & $100 \%$
\end{tabular}

Sumber: Olah Data Responden, 2021

Menurut Amin \& Juniati (2017), pengelompokkan umur terbagi dalam empat kategori, yaitu anakanak, remaja, dewasa dan dewasa lanjut atau lansia. Responden di wisata edukasi pertanian belimbing memiliki usia yang beragam karena wisata ini dapat dikunjungi oleh masyarakat umum dari berbagai kalangan anak-anak, remaja dan orang dewasa. Pada Tabel 1 umur yang paling mendominasi adalah pengunjung dengan kategori umur remaja yaitu sekitar 12-25 tahun dengan presentase $51 \%$ dari data keseluruhan. Tentunya umur dapat menjadi faktor penentu mengenai respon pengunjung terhadap materi yang telah disampaikan pada saat berkunjung ditempat wisata. Karena disetiap golongan umur seseorang memiliki perbedaan mengenai tingkat kecerdasan, mengingat dan memahami suatu hal. Selain itu, jika pada bidang pertanian pada umur 12-25 dapat menjadi peluang besar sebagai sarana untuk meningkatkan regenerasi petani, sehingga kedepan regenerasi petani dapat terjamin dan sumber daya alam dapat lebih termanfaatkan dengan baik.

\section{Tingkat Pendidikan}

Pendidikan merupakan suatu jenjang dimana seseorang menimba ilmu untuk belajar mengenai beberapa hal yang ingin diketahuinya dan mencari wawasan yang luas untuk bekal dimasa yang akan datang. Begitu juga dengan dampak dari pendidikan itu sendiri, dimana semakin rendah atau semakin tinggi pendidikan yang dimiliki oleh pengunjung maka akan mempengaruhi dari penyerapan informasi atau materi yang telah disampaikan dan dibaca (Thamrin et al., 2012). Pendidikan juga mampu menjadi faktor penentu mengenai penilaian atau penyaringan informasi yang telah disebarkan, sehingga penyerapan lebih sesuai dengan harapan individual itu sendiri.

Tabel 2. Distribusi Pengunjung Berdasarkan Tingkat Pendidikan

\begin{tabular}{clcc}
\hline No. & Pendidikan & Jumlah (Orang) & Persentase (\%) \\
\hline 1. & SD & 31 & 24 \\
2. & SMP & 35 & 27 \\
3. & SMA & 53 & 41 \\
4. & Sarjana & 10 & 8 \\
\hline \multicolumn{2}{l}{ Jumlah } & 129 & $100 \%$
\end{tabular}

Sumber: Olah Data Responden, 2021

Berdasarkan Tabel 2 data penelitian terkait dengan tingkat pendidikan, jumlah pendidikan responden yang paling rendah yaitu pendidikan sarjana dan SD, sedangkan responden terbanyak pada kategori tingkat pendidikan SMA/SMK sebanyak 53 responden dan juga tingkat pendidikan SMP sebanyak 35 responden. Menurut Hariyani et al. (2014), tingkat pendidikan dari responden dapat mempengaruhi kemampuan responden untuk menerima dan memahami informasi yang diberikan. Pendidikan mampu membuat seseorang untuk meningkatkan pengetahuan dan wawasannya mengenai banyak hal yang berada disetiap jenjang tertentu. Selain itu pendidikan SMA/SMK memiliki daya serap yang lebih baik dibandingkan dengan tingkat pendidikan dibawahnya, dikarenakan semakin tinggi jenjang pendidikan yang dilalui oleh seseorang akan menambahkan ilmu dan pengalaman yang mereka dapat (Hidayat et al., 2017). 


\section{Pekerjaan Pengunjung}

Pekerjaan merupakan suatu bidang untuk seseorang berusaha dan mendapatkan suatu penghasilan sebagai wujud memenuhi kebutuhan hidupnya. Pekerjaan pengunjung wisata edukasi pertanian sangat beragam, mulai dari tidak bekerja (ibu rumah tangga, pelajar, mahasiswa), petani, pedagang, swasta, wiraswasta dan PNS. Pada Tabel 3 pekerjaan pengunjung yang paling dominan pada wisata edukasi pertanian di kelompok tani belimbing artha mandiri yaitu kategori tidak bekerja dan dominan yang berstatus sebagai pelajar dan mahasiswa. Kategori pelajar dan mahasiswa yang dominan akan berdampak kepada tingkat pendapatan responden, dikarenakan pelajar dan mahasiswa belum memiliki pendapatan tetap hasil jerih payah sendiri dan masih menerima uang saku dari orang tua. Di era saat ini, pelajar dan mahasiswa sudah sadar mengenai pentingnya ilmu pertanian untuk keadaan seharihari. Selain itu ilmu pengetahuan mengenai pertanian bagi pelajar dan mahasiswa dapat menjadi bekal untuk masa depan mereka, sehingga masa depan tidak akan terlalu bingung mengenai cara hidup di dunia tentunya dengan pemanfaat sumber daya alam sekitar. Menurut Ukkas (2017), umur yang produktif contohnya adalah pada seseorang yang sedang melaksanakan proses pembelajaran seperti pelajar dan mahasiswa memiliki potensi besar dalam melaksanakan aktifitas pekerjaan dan proses kegiatan yang mengasah ilmu pengetahuan, sikap dan keterampilannya. Selain itu, dengan banyaknya pelajar dan mahasiswa yang datang ke tempat wisata edukasi pertanian, akan menjadikan sarana sebagai upaya peningkatan regenerasi pertanian. Karena salah satu percepatan dari proses regenerasi petani untuk mau terjun dalam dunia pertanian salah satunya adalah umur produktif yaitu seperti pelajar dan mahasiswa (Santoso et al., 2020).

Tabel 3. Distribusi Pengunjung Menurut Pekerjaannya

\begin{tabular}{clcc}
\hline No. & \multicolumn{1}{c}{ Pendidikan } & Jumlah (Orang) & Persentase (\%) \\
\hline 1. & Tidak Bekerja & 60 & 47 \\
2. & Petani, Pedagang & 30 & 23 \\
3. & Swasta, Wiraswasta & 25 & 19 \\
4. & PNS & 14 & 11 \\
\hline \multicolumn{2}{c}{ Jumlah } & 129 & $100 \%$ \\
\hline
\end{tabular}

Bagi pekerjaan petani dan pedagang berada pada prosentase sebesar 23\%. Angka ini cukup besar serta bagi petani dan pedagang berkunjung ke tempat wisata edukasi pertanian di kelompok tani belimbing artha mandiri merupakan sarana untuk menambah ilmu-ilmu pertanian organik dan sebagai sarana untuk bermitra pada bidang perdagangan. Saat ini petani lebih sadar bahwasanya pertanian organik menjadi salah satu terobosan untuk menghasilkan produk pertanian sehat, sehingga minat dan kesehatan dari konsumen lebih terjamin. Dengan beragamnya inovasi yang memiliki benefit yang tinggi akan berdampak pada mudahnya petani untuk mengadopsi ilmu-ilmu pertanian yang berada diwisata (Ahmad, 2016).

\section{Tingkat Pendapatan Pengunjung}

Tingkat pendapatan tinggi didasarkan pada Nilai rata-rata Upah Minimum Provinsi Jawa Timur (UMP) yaitu sebesar Rp 1.768.777 yang dibulatkan menjadi Rp.2.000.000 karena pengunjung mayoritas berasal dari Provinsi Jawa Timur. Menurut Maresa et al. (2019), tingkat pendapatan dibagi menjadi 4 kategori jumlah pendapatan per bulan responden yaitu rendah, sedang, tinggi dan sangat tinggi.

Tabel 4. Distribusi Pengunjung Menurut Pekerjaannya

\begin{tabular}{cccc}
\hline No. & \multicolumn{1}{c}{ Pendapatan $(\mathbf{R p})$} & Jumlah $($ Orang) & Persentase (\%) \\
\hline 1. & Rendah $(0-1500000)$ & 83 & 64 \\
2. & Sedang $(1500001-2500000)$ & 26 & 20 \\
3. & Tinggi (2500001-3500000) & 9 & 7 \\
4. & Sangat Tinggi $>3500001$ & 11 & 9 \\
\hline & Jumlah & 129 & 58 \\
\hline
\end{tabular}

Sumber: Olah Data Responden, 2021 
Berdasarkan Tabel 4 data pengunjung terkait pendapatan, responden paling banyak adalah responden yang berada pada kategori rendah yaitu sebanyak 83 responden karena mayoritas pengunjung adalah tidak memiliki pekerjaan yang berstatus pelajar dan masih konsumtif dengan tempat wisata. Selain pelajar juga ada responden yang bekerja sebagai petani atau pedagang masih dalam pendapatan yang rendah. Hal ini dikarenakan harga hasil panen yang kadang terlalu fluktuatif dan tidak bersahabat. Untuk tingkat pendapatan yang sangat tinggi diduduki oleh pengunjung yang bekerja sebagai PNS atau aparatur negara. Hal itu dikarenakan PNS dan aparatur Negara memiliki pendapatan yang pasti setiap bulannya dan relative lebih tinggi dibandingkan pekerjaan lainnya.

\section{Integrasi Media Komunikasi}

Media Komunikasi yang digunakan dalam penelitian ini yaitu media komunikasi personal, media komunikasi sosial meliputi blogspot, instagram, youtube, facebook dan media cetak X-Banner. Seluruh responden atau pengunjung wisata edukasi pertanian mampu mengakses seluruh media massa tersebut. Sehingga memungkinkan banyak sumber informasi dan ilmu pertanian yang didapatkan oleh pengunjung. Integrasi media komunikasi yang diterapkan dalam penelitian lebih mempermudah responden dalam mengakses materi-materi mengenai budidaya belimbing secara organik pada wisata edukasi pertanian. Berdasarkan kuesioner yang telah disebarkan kepada responden, menyatakan media komunikasi personal, media komunikasi sosial dan media komunikasi cetak membantu pengunjung untuk memahami materi yang telah diberikan.

\section{Tingkat Pengetahuan Pengunjung}

Pengetahuan merupakan segala sesuatu yang diketahui berdasarkan pengalaman manusia itu sendiri dan pengetahuan akan bertambah sesuai dengan proses pengalaman yang dialaminya. Tingkat pengetahuan ada 6 tahapan yaitu tahu, memahami, aplikasi, analisis, sintesis dan evaluasi. Namun, pada penelitian ini peneliti menggunakan 2 tahapan yang memungkinkan untuk diujikan kepada responden penelitian, yaitu tahapan tahu dan memahami. Pengukuran aspek pengetahuan pengunjung dilakukan dengan menggunakan.

Analisa Skoring Rerata Jawaban Kuisioner yang berdasarkan pada hasil jawaban responden pada kuisioner yang diberikan. Isi kuisioner berhubungan dengan materi yang disampaikan pada saat pengunjung berada di lokasi wisata. Kuesioner yang diberikan untuk pengukuran tingkat pengetahuan sebanyak 21 butir pernyataan yang berkaitan dengan kemampuan sasaran dalam gambaran umum mengenai budidaya belimbing organik. Berdasarkan hasil data kuesioner menunjukkan jawaban kuesioner pengunjung terhadap tingkat pengetahuan mengenai materi budidaya belimbing organik. Diketahui sebanyak 129 orang berada tahap memahami, yang berarti keseluruhan pengunjung dapat memahami materi dengan baik yang disampaikan oleh pengelola serta materi yang telah diupload melalui media sosial dan media cetak.

\section{Pengaruh Karakteristik Pengunjung terhadap Tingkat Pengetahuan Pengunjung}

\section{Umur}

Tabel 5. Pengaruh Variabel Independen terhadap Pengetahuan pengunjung

\begin{tabular}{|c|c|c|c|c|c|c|c|}
\hline \multirow[t]{2}{*}{ Model } & \multicolumn{2}{|c|}{$\begin{array}{l}\text { Unstandardized } \\
\text { Coefficients }\end{array}$} & \multirow{2}{*}{$\begin{array}{l}\text { Standardized } \\
\text { Coefficients } \\
\text { Beta }\end{array}$} & \multirow[t]{2}{*}{$\mathbf{t}$} & \multirow[t]{2}{*}{ ig. } & \multicolumn{2}{|c|}{ Collinearity Statistics } \\
\hline & B & Std. Error & & & & Tolerance & VIF \\
\hline (Constant) & 6.230 & .721 & & 8.636 & .000 & & \\
\hline X1.1 Umur & .018 & .009 & .116 & 1.997 & .048 & .508 & 1.968 \\
\hline X1.2 Tingkat Pendidikan & .975 & .114 & .514 & 8.538 & .000 & .473 & 2.116 \\
\hline X1.3 Pekerjaan & -.463 & .175 & -.242 & -2.648 & .009 & .204 & 4.906 \\
\hline X1.4 Tingkat Pendapatan & .328 & .152 & .167 & 2.161 & .033 & .286 & 3.495 \\
\hline X2.1 Media Personal & .358 & .110 & .154 & 3.250 & .001 & .762 & 1.312 \\
\hline X2.2 Media Sosial & .690 & .122 & .336 & 5.648 & .000 & .483 & 2.071 \\
\hline X2.3 Media Cetak & .908 & .201 & .200 & 4.524 & .000 & .871 & 1.148 \\
\hline
\end{tabular}

Sumber: Analisis Data Responden, 2021

Umur merupakan salah satu faktor dari pengunjung yang dapat mempengaruhi dari daya penyerapan informasi yang telah diberikan. Setelah dilakukannya analisa data terkait penelitian pada wisata edukasi pertanian, didapatkan seperti Tabel 5. Berdasarkan Tabel 5 nilai signifikansi sebesar 0,048 dan 
kurang dari 0,05 hal ini berarti umur pengunjung mampu mempengaruhi pengetahuan pengunjung terkait materi yang telah disampaikan. Jika dilihat pada $t$ hitung, $t$ hitung dan koefisien regresi pada variabel umur bernotasi pengaruh positif, hal ini menandakan pengaruh yang diberikan tidak bersifat berbalik. Hal ini juga disesuai dengan penelitian Suwaryo \& Yuwono (2017), bahwa usia seseorang juga mempengaruhi terhadap daya tangkap, pola pikir dan pengetahuan seseorang. Semakin bertambah usia akan semakin berkembang pula daya tangkap dan pola pikirnya, sehingga pengetahuan yang diperolehnya semakin baik. Selain itu, menurut Indriantoro (2014) bahwa umur individu yang terhitung mulai saat dilahirkan hingga bertambah dari tahun ketahun. Semakin cukup umur, tingkat kematangan seseorang akan lebih matang dalam berpikir dan bekerja serta hal itu juga berpengaruh terhadap kognitif seseorang. Fakta dilapangan menunjukkan umur yang lebih produktif atau lebih muda memiliki antusiasme yang lebih tinggi dalam bertanya dan berinteraksi pada lokasi wisata sehingga masih membutuhkan waktu yang berulang-ulang agar mampu memahami materi yang diberikan, sedangkan pada usia yang lebih tua menunjukkan proses interaksi yang bersifat implementasi sebagai upaya bentuk pemahaman mendalam.Fakta dilapangan juga didukung dengan penelitian yang dilakukan oleh (Yuswantina et al., 2019) serta pada buku (Budiman \& Riyanto, 2014) berpendapat bahwa tingkat intelektual atau pengetahuan seseorang akan semakin tinggi dengan bertambahnya umur seseorang tersebut.

\section{Tingkat Pendidikan}

Tingkat pendidikan pengunjung merupakan karakteristik yang dapat mempengaruhi daya penyerapan informasi dan daya memaknai materi yang telah diberikan. Selain itu menurut Sriyono (2015), pendidikan merupakan sebuah proses bertahap yang telah dilalui dengan sistematis dan terstruktur serta memiliki aturan yang mengikat sehingga dalam pelaksanaannya melibatkan pihak-pihak dalam proses belajar mengajar. Semakin tinggi tingkat pendidikan seseorang, semakin tinggi juga wawasan, pengalaman serta pengetahuan yang telah dimiliki. Selain itu menurut Thamrin et al. (2012) dan Romadi et al. (2021), tingkat pendidikan mampu mempengaruhi penyerapan informasi yang telah diberikan.

Pendidikan juga mampu menjadi faktor penentu mengenai penilaian atau penyaringan informasi yang telah disebarkan, sehingga penyerapan lebih sesuai dengan harapan individual itu sendiri. Pada Tabel 5 nilai sig tingkat pendidikan adalah 0,000 yang berarti adanya pengaruh signifikan yang sangat tinggi antara tingkat pendidikan terhadap pengetahuan pengunjung wisata. Jika dilihat dari t hitung dan koefisien regresi menunjukkan pengaruh yang bernotasi positif. Hal ini berarti semakin tinggi pendidikan pengunjung, maka akan semakin tinggi pula tingkat pengetahuan pengunjung mengenai materi yang diberikan pada saat berkunjung di wisata edukasi pertanian.

Selain itu, pendidikan yang tinggi juga berdampak pada tingkat kreatifitas dan pola pikir aktif seseorang yang mengakibatkan fungsi otak yang cenderung optimal. Hal ini sesuai dengan penelitian Carter (2008), bahwa semakin tinggi tingkat pendidikan seseorang akan semakin mudah menerima informasi sehingga semakin banyak pula pengalaman yang dimiliki. Pendidikan pada diri individu akan berpengaruh terhadap kemampuan berfikir, semakin tinggi tingkat pendidikan akan semakin mudah berfikir rasionalisme dan menangkap informasi baru termasuk dalam menguraikan masalah yang baru. Menurut penelitian dari Dharmawati \& Wirata (2016), adanya hubungan antara tingkat pendidikan dengan tingkat pengetahuan, karena tidak dapat dipungkiri bahwa makin tinggi pendidikan seseorang semakin tinggi pula mereka menerima informasi dan pada akhirnya makin banyak pula pengetahuan yang dimilikinya. Sebaliknya jika seseorang tingkat pendidikannya rendah, akan menghambat perkembangan sikap seseorang terhadap penerimaan informasi dan nilai-nilai yang baru diperkenalkan.

\section{Pekerjaan}

Pekerjaan pengunjung sangat bervareasi sesuai dengan keahliannya masing-masing. Dalam klasifikasi pada penelitian ini pekerjaan pengenjung terdiri dari tidak bekerja (ibu rumah tangga, pelajar, mahasiswa), petani, pedagang, swasta, wiraswasta dan PNS. Pekerjaan tersebut memiliki tujuannya masing-masing dan job masing-masing yang salah satunya untuk memenuhi kesejahteraan individu atau kelompok.

Berdasarkan Tabel 5, nilai signifikan menunjukkan angka sebesar 0,009 dan lebih kecil dari 0,05. Hal ini menunjukkan adanya pengaruh signifikan antara pekerjaan terhadap tingkat pengetahuan 
pengunjung. Akan tetapi jika dilihat pada t hitung dan koefisien regresi menunjukkan notasi pengaruh negatif. Sehingga semakin rendah klasifikasi pekerjaan yang ditentukan maka tingkat pengetahuan akan semakin tinggi. Hal ini dikarenakan, pada penelitian ini, klasisfikasi pekerjaan digolongkan sebagai berikut: Tidak Bekerja (ibu rumah tangga, pelajar dan mahasiswa), Petani dan Pedagang, Swasta dan Wiraswasta, PNS. Hal tersebut dapat menjadi faktor nilai signifikan yang bernotasi negatif, dimana jika pekerjaan pada kategori petani atau tidak bekerja nilai pengetahuan akan semakin tinggi.

Penelitian yang dilakukan oleh Muthmainnah (2010), menjelaskan bahwa pekerjaan seseorang akan berpengaruh terhadap pengetahuan dan pengelaman seseorang. Penjelasan mengapa pekerjaan berpengaruh terhadap seseorang adalah ketika pekerjaan tersebut lebih sering menggunakan otak daripada menggunakan otot. Kinerja dan kemampuan otak seseorang dalam menyimpan (daya ingat) bertambah atau meningkat ketika sering digunakan, hal ini berbanding lurus ketika pekerjaan seseorang lebih banyak menggunakan otak daripada otot.

\section{Tingkat Pendapatan}

Pendapatan merupakan hasil atau pemasukan bulanan dari setiap individu pengunjung wisata. Tentunya pendapatan pengunjung sangat beragam. Pendapatan pengunjung dapat mempengaruhi pola pikir atau pandangan seseorang terhadap sesuatu.

Berdasarkan Tabel 5 nilai sig sebesar 0,017 dan lebih kecil dari nilai alpha sebesar 0,05. Selain itu pada nilai t hitung dan nilai koefisien regresi menunjukkan notasi positif. Hal ini menunjukkan adanya pengaruh positif yang signifikan antara tingkat pendapatan terhadap pengetahuan pengunjung wisata. Ternyata semakin tinggi tingkat pendapatan seseorang dapat mempengaruhi pengetahuan atau daya serap seseorang. Hal itu salah satunya dapat disebabkan karena semakin tingginya pendapatan, seseorang akan lebih nyaman dan lebih merasa leluasa dalam penyerapan informasi yang telah diberikan. Hal ini sesuai dengan penelitian Septalia (2010), yang menyatakan bahwa semakin tinggi tingkat sosial ekonomi seseorang, semakin mudah pula dalam menerima informasi baru.

\section{Pengaruh Karakteristik Pengunjung terhadap Pengetahuan Pengunjung}

Variabel karakteristik pengunjung merupakan segala data atau sifat-sifat yang ada pada diri pribadi pengunjung. Karakteristik pengunjung seringkali menjadi faktor dalam mempengaruhi variabel dependen. Pada penelitian ini karakteristik pengunjung terdiri dari umur, tingkat pendidikan, pekerjaan dan tingkat pendapatan. Data yang telah didapatkan dari responden atau pengunjung wisata edukasi pertanian kelompok tani belimbing artha mandiri, telah dianalisis regresi linear berganda dengan menggunakan program SPSS dan telah ditampilkan pada Tabel 6.

Tabel 6. Pengaruh Karakteristik Pengunjung terhadap Pengetahuan Pengunjung

\begin{tabular}{lccccc}
\hline \multicolumn{1}{c}{ Model } & Sum of Squares & df & Mean Square & F & Sig. \\
\hline Regression & 248.218 & 4 & 62.055 & 52.211 & $.000^{\mathrm{b}}$ \\
Residual & 147.378 & 124 & 1.189 & & \\
Total & 395.597 & 128 & & & \\
\hline
\end{tabular}

Sumber: Analisis Data Responden, 2021

Berdasarkan analisis data secara bersamaan mengenai data karakteristik pengunjung, didapatkan nilai sig sebesar $0,000<0,05$ dan bernotasi positif. Berdasarkan data tersebut menunjukkan karakteristik pengunjung mampu mempengaruhi pengetahuan pengunjung secara positif dan signifikan, yang berarti semakin baik karakteristik pengunjung semakin tinggi pula pengetahuan pengunjung, sehingga dalam penyampaian informasi perlu mempertimbangkan karakteristik pengunjung agar segala informasi yang diberikan mampu diserap baik oleh pengunjung wisata.

\section{Pengaruh Integrasi Media Komunikasi dengan Pengetahuan Pengunjung}

\section{Media Personal}

Media Personal mendukung adanya interaksi interpersonal antara anggota keluarga, teman, rekan dan orang-orang yang kita ketahui. Media personal memberikan pengetahuan atau materi yang lebih detaildan bersifat face to face, sehingga kita mampu mengetahui maksud dari yang komunikator secara langsung. Namun, tidak selamanya media personal dianggap sangat efektif, karena masalahnya media personal akan bersifat lebih efektif jika sang komunikator mampu mengatur situasi saat pelaksanaan 
pemberian materi serta komunikator harus mampu berbahasa sesuai dengan karakteristik audience. Pada penelitian ini, pengaruh media personal terhadap pengetahuan pengunjung telah disajikan pada Tabel 5 .

Berdasarkan analisis data, nilai sig sebesar 0,033 dan lebih kecil dari 0,05. Selain itu jika dilihat pada standart koefisien regresi berada pada angka 0.167 dan angka t hitung sebesar 2.161. Dari data tersebut, dapat disimpulkan bahwasanya media personal mampu mempengaruhi tingkat pengetahuan pengunjung secara signifikan.

Fakta di lapangan menunjukkan metode yang dilakukan dalam media personal adalah penyampaian materi secara langsung, sehingga terdapat ruang terbuka bagi seluruh pengunjung untuk bertanya mengenai hal-hal yang ingin mereka tanyakan, selain itu media personal memberikan peluang untuk semua orang sebagai partisipan yang aktif dan kreatif dalam memahami materi dan menganalisa materi yang telah disampaikan pengelola secara langsung. Menurut Atsani (2020), dengan metode pembelajaran melalui system offline atau tatap muka komunikan mampu aktif bertanya seputar materi yang diberikan secara langsung sehingga mampu mendukung proses penyerapan informasi yang diberikan.

\section{Media Sosial}

Penggunaan akan perangkat teknologi seperti komputer, smartphone atau tablet mengalami peningkatan yang sangat tinggi. Hal tersebut juga berbanding lurus dengan kebutuhan akan jaringan internet. Banyak hal yang dapat dilakukan, dan media sosial adalah salah satu fitur yang paling sering digunakan oleh pengguna internet saat ini. Media sosial merupakan suatu media secara online yang digunakan untuk kebutuhan komunikasi, menyampaikan informasi atau berdiskusi jarak jauh. Pada penelitian kali ini, media sosial yang digunakan cukup bervareasi, antara lain: blogspot, facebook, instagram dan youtube. Dimana vareasi yang telah disajikan ini diharapkan mampu untuk memberikan peluang bagi minat individu tiap pengunjung yang hadir. Berdasarkan penelitian analisis data terkait pengaruh media sosial telah tersaji pada Tabel 5.

Untuk melihat apakah media sosial dapat mempengaruhi pengetahuan pengunjung atau tidak, dapat dilihat dari nilai sig < dari nilai alpha 0,05 . Berdasarkan analisis data diatas nilai sig sebesar 0,000 dan lebih kecil dari nilai alpha yang telah ditentukan, serta jika dilihat dari thitung bernotasi positif. Hal ini dapat disimpulkan adanya pengaruh positif secara signifikan antara media sosial terhadap pengetahuan pengunjung. Yang berarti, semakin intens pengunjung melihat dan membaca materi melalui berbagai media sosial, peningkatan pengetahuan akan semakin tampak dan lebih baik darisebelumnya. Hal itu sejalan dengan penelitian dari Aisyah et al. (2020) dan Nugrohoi (2014), bahwa intervensi melalui media sosial dapat mempengaruhi peningkatan pengetahuan mengenai materi yang telah diberikan.

Dengan digunakannya ragam media komunikasi khususnya media sosial, memungkinkan pengunjung dapat memilih karakter materi yang lebih nyaman dibaca pada setiap individunya, sehingga materi yang diserap akan lebih cepat. Karena setiap karakter seseorang berbeda-beda, ada yang senang membaca karena design templatenya menarik dan mudah dibaca, ada yang senang membaca materi yang singkat dan padat saja, ada juga yang gemar membaca secara medetail dan ada juga individu yang membutuhkan peragaan melalui video secara langsung untuk memungkinkan meningkatkan pemahaman terkait materi yang disajikan, sehingga fakta di lapangan menunjukkan pengunjung mampu menelaah dan memaknai materi dengan cepat dan nyaman.

\section{Media Cetak}

Media cetak merupakan suatu media yang bersifat tertulis atau tercetak. Di dalam pemaparan melalui media cetak, materi yang dikemas dapat didesign secara fleksibel, dinamis dan materi yang disampaikan pun dapat bersifat jelas dan detail. Dengan adanya materi yang seperti ini, nantinya kan mampu membuat pengunjung untuk tertarik membaca apa yang ada pada media cetak tersebut. Penelitian ini menggunakan media cetak X-Banner sehingga sangat efektif dan dapat diletakkan dimana-mana sesuai keinginan. Pengaruh media cetak terhadap pengetahuan pengunjung, dapat dilihat pada Tabel 5.

Dengan adanya analisis data regresi linear berganda, kita mampu melihat seberapa pengaruh antar vareabel independent dan dependent. Berdasarkan Tabel 5, nilai sig dari media cetak terhadap pengetahuan pengunjung adalah 0,000 . Angka tersebut dinyatakan berpengaruh karena kurang dari 
nilai alpha sebesar 0,05. Dengan demikian media cetak mampu mempengaruhi pengetahuan pengunjung secara signifikan dan bernotasi positif. Hal ini sesuai dengan penelitian dari Gafi et al. (2020), bahwa media cetak mampu mempengaruhi pengetahuan seseorang. Media cetak mampu mempengaruhi secara signifikan, hal ini dikarenakan Bahasa, materi dan design yang dipaparkan dibuat seenarik mungkin dan senyaman mungkin untuk dilihat, sehingga pengunjung mampu memahami materi lebih cepat dan pemahaman pengunjung dapat nilai lebih baik penyerapannya.

\section{Integrasi Media Komunikasi terhadap Pengetahuan Pengunjung}

Media komunikasi sangat berfungsi dalam memberikan informasi dan ilmu-ilmu pengetahuan terhadap komunikan. Media komunikasi yang kompleks akan mempermudah pemahaman dari pengunjung wisata. Pada penelitian ini media komunikasi yang digunakan adalah media personal, media sosial (blogspot, instagram, facebook dan youtube) dan media cetak (X-Banner). Berbagai media komunikasi yang digunakan dapat melengkapi dari karakteristik pengunjung dan bersifat fleksibel sesuai dengan keadaan dan dapat dilihat dimanapun. Hasil analisis data terkait integrasi media komunikasi terhadap Pengunjung Pengetahuan dapat dilihat pada Tabel 7.

Tabel 7. Pengaruh Integrasi Media Komunikasi terhadap Pengetahuan Pengunjung

\begin{tabular}{lccccc}
\hline \multicolumn{1}{c}{ Model } & Sum of Squares & df & Mean Square & F & Sig. \\
\hline Regression & 248.839 & 3 & 82.946 & 70.649 & $.000^{\mathrm{b}}$ \\
Residual & 146.757 & 125 & 1.174 & & \\
Total & 395.597 & 128 & & & \\
\hline
\end{tabular}

Sumber: Analisis Data Responden, 2021

Hasil yang didapatkan, nilai sig sebesar 0,000 dan bernotasi positif. Dari angka tersebut dapat disimpulkan nilai sig lebih kecil dari nilai alpha 0,000 dan tergolong pada signifikansi sangat baik serta berarti integrase media komunikasi mampu mempengaruhi pengetahuan pengunjung, sehingga semakin intens pengunjung untuk melihat materi dari berbagai media komunikasi yang disajikan, semakin tinggi pula pengetahuan atau pemahaman pengunjung terhadap materi yang diberikan. Dengan adanya berbagai sumber media informasi yang disajikan memungkinkan pengunjung dapat mengakses sesuai dengan karakteristik dan minat membaca dari setiap karakteristik individu pengunjung wisata.

Pengaruh hasil analisa data yang bernotasikan positif didukung dengan argument Siregar \& dkk (2021), manusia cederung memiliki sifat suka memperhatikan, membaca atau mendengarkan pesan yang dirasakan. Adanya berbagai media yang digunakan, mampu memompa indera manusia untuk menangkap segala informasi yang telah diberikan. Selain itu Knapp (1998), berpendapat komunikasi merupakan sebagian proses interaksi antarpribadi yang menggunakan suatu isyarat berupa symbol linguistik (verbal dan non verbal). Pada sistem tersebut manusia mampu menangkap sesuatu informasi yang disosialisasikan baik secara personal (face to face) atau melalui media lainnya.

\section{KESIMPULAN}

Karakteristik pengunjung pada wisata edukasi pertanian di kelompok tani belimbing artha mandiri dari segi umur yang banyak melakukan kunjungan adalah umur 12-25 tahun dengan prosentase $51 \%$ dan tergolong dalam kategori remaja. Berdasarkan pada tingkat pendidikan, rata-rata pengunjung berada pada rerata pendidikan SMA/SMK Se-derajat dengan presentase $41 \%$. Pada segi pekerjaan, rata-rata pekerjaan adalah tidak bekerja (ibu rumah tangga, pelajar dan mahasiswa) dengan prosentase $47 \%$. Pada tingkat pendapatan pengunjung rerata pada kategori rendah yaitu berkisar Rp. 0 - Rp. 1.500.000, sedangkan pada pengaruh karakteristik pengunjung dan integrasi media komunikasi terhadap pengetahuan pengunjung data menunjukkan adanya pengaruh positif yang signifikan antara karakteristik pengunjung terhadap pengetahuan pengunjung dengan nilai signifikan $0,000<0,05$. Hal ini berarti setiap peningkatan karakteristik pengunjung meliputi umur, tingkat pendidikan, pekerjaan dan tingkat pendapatan diiri dengan peningkatan pengetahuan pengunjung wisata.

Selain itu, pengaruh integrasi media komunikasi terhadap pengetahuan pengunjung didapat signifikan $0,000<0,05$, sehingga dapat dinyatakan adanya pengaruh positif yang signifikan antara integrasi media komunikasi terhadap pengetahuan pengunjung wisata. Hal ini dapat diartikan, semakin sering pengunjung membaca atau mendengarkan dari ragam media komunikasi yang digunakan pada wisata 
edukasi, pengunjung akan semakin memahami materi yang disampaikan oleh pengelola wisata edukasi, sedangkan berdasarkan hasil analisa data secara keseluruhan variabel yang paling berpengaruh untuk meningkatkan pengetahuan pengunjung adalah dengan menggunakan media sosial sebagai penyampaian informasi dan komunikasi.

Peneliti maupun penulis lainnya dapat menjadikan penelitian ini sebagai landasan penelitian berikutnya. Pada penelitian yang akan datang, dapat dikaji mengenai efektivitas dari ragam media komunikasi yang ada terhadap pengetahuan pengunjung atau terhadap variabel dependent lainnya. Selain itu dapat juga meneliti mengenai seberapa jauh content yang dipaparkan melalui media komunikasi dapat merubah perilaku dari pengunjungnya.

\section{UCAPAN TERIMA KASIH}

Diucapkan banyak-banyak terimakasih kepada segala pihak yang telah membantu penelitian ini dari awal hingga selesai. Semoga menjadi amal jariyah untuk semuanya dan penelitian ini mampu memberikan manfaat kepada pembaca.

\section{DAFTAR PUSTAKA}

Ahmad, Y. (2016). Pengaruh Karakteristik Inovasi Pertanian Terhadap Keputusan Adopsi Usaha Tani Sayuran Organik. 6(2), 1-14.

Aisyah, S., Syafar, M., \& Amiruddin, R. (2020). Pengaruh Media Sosial Untuk Meningkatkan Pengetahuan Dan Sikap Remaja Tentang Hiv \& Aids Di Kota Parepare. Jurnal Kesehatan Masyarakat Maritim, 3(1), 109-122. https://doi.org/10.30597/jkmm.v3i1.10299

Amin, M. Al, \& Juniati, D. (2017). Klasifikasi Kelompok Umur Manusia Berdasarkan Analisis Dimensi Fraktal Box Counting Dari Citra Wajah Dengan Deteksi Tepi Canny. Jurnal Ilmiah Matematika, 2(6), 1-10. https://jurnalmahasiswa.unesa.ac.id/index.php/mathunesa/ article/view/ 19398

Atsani, K. L. G. M. Z. (2020). Transformasi media pembelajaran pada masa pandemi Covid-19 (Transformation of learning media during Covid-19 pandemic). Al-Hikmah: Jurnal Studi Islam, 1(1), 82-93.

Batubara, A. K. (2011). Urgensi Kompetensi Komunikasi Pustakawan Dalam Memberikan Layanan Kepada Pemustaka. Jurnal Iqra' Volume 05 No.1, 5(01), 50. http://repository.uinsu.ac.id/643/1/(7) Urgensi Kompetensi Komunikasi Pustakawan dalam Memberikan Layanan Kepada Pemustaka.pdf diakses tanggal 21 Desember 2019 pukul 11.51 WIB

Budiman, \& Riyanto, A. (2014). Kapita Selekta Kuesioner Pengetahuan dan Sikap dalam Penelitian Kesehatan. Salemba Medika.

Carter, W. N. (2008). Disaster Management. Disaster Manegement: A Disaster Manager's Handbook. Manila: Adb.

Dharmawati, I. G. A. A., \& Wirata, I. N. (2016). Hubungan Tingkat Pendidikan, Umur, Dan Masa Kerja Dengan Tingkat Pengetahuan Kesehatan Gigi Dan Mulut Pada Guru Penjaskes Sd Di Kecamatan Tampak Siring Gianyar. Jurnal Kesehatan Gigi, 4(1), 1-5. http://www.poltekkesdenpasar.ac.id/keperawatangigi/wp-content/uploads/2017/02/ilovepdf_merged.pdf

Gafi, A. Al, Hidayat, W., \& Tarigan, F. L. (2020). Pengaruh Penggunaan Media Sosial Whatsapp Dan Booklet Terhadap Pengetahuan Dan Sikap Siswa Tentang Rokok Di Sma Negeri 13 Medan. Jurnal Muara Sains, Teknologi, Kedokteran Dan Ilmu Kesehatan, 3(2), 281. https://doi.org/10.24912/jmstkik.v3i2.5656

Hariyani, E. B., Mardikanto, T., \& Ihsaniyati, H. (2014). Persepsi Petani Terhadap Program Gerakan Peningkatan Produksi Pangan Berbasis Korporasi (GP3K) Di Desa Jati Kecamatan Jateng Kabupaten Karanganyar. Jurnal Program Studi Agribisnis Fakultas Pertanian Universitas Sebelas Maret, 4(11), 1-11. https://docplayer.info/82776449-Persepsi-petani-terhadappengembangan-system-of-rice-intensification-sri-di-kecamatan-moga-kabupaten-pemalang.html

Hidayat, T., Yulida, R., \& Rosnita. (2017). Karakteristik Petani Padi Peserta Program Upaya Khusus Padi Jagung Kedelai Upsus Pajale Di Desa Ranah Baru Kecamatan Kampar Kabupaten 
Kampar. 4(76), 26-28.

Indriantoro. (2014). Pengetahuan Masyarakat Terhadap Mitigasi Bencana Kekeringan Di Kecamatan Tawangsari Kabupaten Sukoharjo. In Universitas Muhammadiyah Surakarta (Issue c). http://eprints.ums.ac.id/27997/

Janssen, S. J. C., Porter, C. H., Moore, A. D., Athanasiadis, I. N., Foster, I., Jones, J. W., \& Antle, J. M. (2017). Towards a new generation of agricultural system data, models and knowledge products: Information and communication technology. Agricultural Systems, 155, 200-212. https://doi.org/10.1016/j.agsy.2016.09.017

Joo, Y., Seok, H., \& Nam, Y. (2020). The moderating effect of social media use on sustainable rural tourism: A theory of planned behavior model. Sustainability (Switzerland), 12(10), 1-14. https://doi.org/10.3390/su12104095

Knapp, K. (1998). Meeting the Intercultural Challenge.

Maresa, K. I., Restu, I. W., \& Ekawaty, R. (2019). Inventarisasi Jenis Ikan yang Didaratkan dan Kondisi Sosial. Current Trends in Aquatic Science II, 2(1), 29-36. https://ojs.unud. ac.id/index.php/CTAS/article/view/43592

Mittal, S., \& Mehar, M. (2016). Socio-economic Factors Affecting Adoption of Modern Information and Communication Technology by Farmers in India: Analysis Using Multivariate Probit Model. Journal of Agricultural Education and Extension, 22(2), 199-212. https://doi.org/10.1080/ 1389224X.2014.997255

Muthmainnah, F. (2010). Faktor-faktor yang Berhubungan dengan Pengetahuan Ibu dalam Memberikan Makanan Pendamping Air Susu Ibu di Puskesmas Pamulang 2010. Skripsi. Fakultas Kedokteran Dan Ilmu Kesehatan UIN Syarif Hidayatullah Jakarta, 1-101.

Narangajavana, Y., Callarisa Fiol, L. J., Moliner Tena, M. Á., Rodríguez Artola, R. M., \& Sánchez García, J. (2017). The influence of social media in creating expectations. An empirical study for a tourist destination. Annals of Tourism Research, 65, 60-70. https://doi.org/10.1016/ j.annals.2017.05.002

Nugrohoi, C. V. (2014). Melalui Grup Facebook Terhadap Pengetahuan Remaja. Jurnal Promkes, 2(2), 128-139.

Romadi, U., Gunawan, \& Pramita, Y. (2021). Development of Sustainable Agrotourism Based on Social Capital in Tourism-Aware Community Groups in Pujonkidul Village , Pujon District, Malang Regency , East. PalArch's Journal of Archaeology of ..., 18(5), 328-342. https://archives.palarch.nl/index.php/jae/article/view/7911

Santoso, A. W., Effendy, L., \& Krisnawati, E. (2020). Percepatan Regenerasi Petani Pada Komunitas Usahatani Sayuran Di Kecamatan Samarang Kabupaten Garut Provinsi Jawa Barat. Jurnal Inovasi Penelitian, 1(3), 325-336. https://doi.org/10.47492/jip.v1i3.59

Septalia, R. E. (2010). Penyuluhan Kesehatan Masyarakat. http://creasoft.wordpress.com

SIREGAR, R. T., \& dkk. (2021). KOMUNIKASI ORGANISASI (1st ed.). Widina Bhakti Persada Bandung. http://digilib.uinsgd.ac.id/40787/1/Komunikasi Organisasi Cetak.pdf

Sriyono. (2015). Pengaruh Tingkat Pendidikan dan Pemahaman Masyarakat Tentang Ikan Berformalin terhadap Kesehatan Masyarakat. Jurnal Faktor Exacta, 8(1), 79-91.

Sugiyono. (2018). Metode Penelitian Kuantitatif, Kualitatif dan R\&D. Alfabeta.

Suri, D. (2019). Pemanfaatan Media Komunikasi dan Informasi dalam Perwujudan Pembangunan Nasional. Jurnal Komunikasi Pembangunan, 17(2), 177-187. https://doi.org/10.46937/ 17201926848

Suwaryo, P. A. W., \& Yuwono, P. (2017). Faktor-faktor yang mempengaruhi tingkat pengetahuan masyarakat dalam mitigasi bencana alam tanah longsor. Urecol 6th, 305-314. http://journal. ummgl.ac.id/index.php/urecol/article/view/1549

Teni Nurrita. (2018). Kata Kunci :Pengembangan media pembelajaran untuk meningkatkan hasil belajar siswa. Jurnal Misykat, 03(01), 171.

Thamrin, M., Herman, S., \& Fahrul, H. (2012). Pengaruh Faktor Sosial Ekonomi Terhadap Pendapatan Petani Pinang. Agrium, 17(2), 103-108. http://jurnal.umsu.ac.id/index.php/agrium/ article\%0A/view/277 
Ukkas, I. (2017). Faktor-Faktor Yang Mempengaruhi Produktivitas Tenaga Kerja Industri Kecil Kota Palopo. Kelola: Journal of Islamic Education Management, 2(2). https://doi.org/10.24256/kelola. $\mathrm{v} 2 \mathrm{i} 2.440$

Yuswantina, R., Dyahariesti, N., Sari, N. L. F., \& Sari, E. D. K. (2019). Hubungan Faktor Usia dan Tingkat Pendidikan Terhadap Pengetahuan Penggunaan Antibiotik di Kelurahan Sidorejo Kidul. Journal of Pharmacy and Natural Product, 2(1), 25-31. 